\title{
Investigation of IFRS16 Effect on the Airlines
}

\author{
Jin Yu \\ Business School, Chengdu University of Technology, Chengdu, P. R. China
}

\section{Email address:}

yujincdut@163.com

\section{To cite this article:}

Jin Yu. Investigation of IFRS16 Effect on the Airlines. Journal of Finance and Accounting. Vol. 7, No. 5, 2019, pp. 132-135. doi: $10.11648 /$ j.jfa.20190705.11

Received: August 10, 2019; Accepted: August 24, 2019; Published: September 9, 2019

\begin{abstract}
Under IAS17, operating leases can be reported in the notes of financial statements, so operating leases are not recognized in statements of financial position, and the lease payments are recognized as expenses and recorded in statements of profit and loss. Therefore, operating leases have the nature of off-balance sheet, and keeping operating leases off of the balance sheet has been the veil of the true nature of a company's liabilities. To increase the transparency of company's lease liabilities, IFRS 16 changes the way that lessees disclose operating leases in their financial statements. and relevant financial ratios including debt to asset ratio, asset turnover ratio and EBITD will also change. PwC, Deloitte, KPMG and Ernst \& Young provide guides to help companies execute the new accounting standard, and they foresee that some industries will be influenced on the basis of the degree of dependence on operating leases. This paper will compare the accounting treatment of leases in IAS17 and IFRS16, and the impact on airlines will be analyzed from financial statements and financial ratios. For operating leases, the advantage of off-balance sheet will disappear, so Airlines that rely heavily on operating leases should consider the impact of lease capitalization on their businesses.
\end{abstract}

Keywords: Lease Accounting, IAS17, IFRS16

\section{Introduction}

To improve the deficiency of IAS17, The International Accounting Standards Board (IASB) has issued the new lease accounting standard, IFRS16, in 2016. It replaces the previous leasing accounting standard, IAS17, and it applies after 1 January 2019 [1]. Some researchers have conducted studies on development and implement of IFRS16 [2, 3]. Under the new accounting standard, lessees do not need to differentiate between operating and finance leases as almost all leases should be identified as finance leases except short-term leases and low-value leases. Financial statements will be influenced by the changes of accounting treatment, because lessees need to recognize a right-of-use asset and corresponding liability in their statements of financial position, while lessees need to recognize the interest on the lease liability and the depreciation expense of the leased asset instead of the previous operating lease expenses. Furthermore, some important financial ratios such as debt to asset ratio, asset turnover ratio and EBITDA will also be affected [4, 5]. Therefore, some industries such as retailers, airlines and telecommunications which are dependent on operating leases will face potential challenges [6-8]. Based on annual reports of three airlines [9-11], IFRS16 effects on the airline will be analyzed.

\section{IAS17}

Under IAS17, leases are classified as operating leases and finance leases. If a lease transfers substantially all the risks and rewards of ownership, it is a finance lease [12]. Especially, companies can disclose the information of operating leases in the notes of financial statements. In this way, companies have more discretion, but off-balance sheet disclosure lacks unified and normative requirements. Due to the fact that Operating leases have not been presented on statements of financial position, the true nature of liabilities has been hidden, the prepared financial statements under the previous standard cannot faithfully represent lease transactions. In addition, the notes of financial statements always include a lot of details, but most ordinary investors would not pay attention to the notes in fact, the important information might not be considered when they make investment decisions, so these problems of IAS17 need to be solved. 


\section{IFRS16}

The new standard IFRS16 has updated the definition of a lease and provided the guidance to distinguish lease contracts and service contracts. The two important criteria to judge a lease are identified asset and right to control the use of the identified asset, and the second criterion includes the right to obtain substantially all economic benefits and direct the use [13]. More importantly, if a contract combines lease and non-lease payments, the part of lease should be separate from the part of non-lease. For lessees, the main change of new standard is that all leases should be regarded as finance leases except short-term leases (less than or equal to 12 months) and low-value leases (less than or equal to \$5,000) [1]. Firstly, lessees should recognize a right of use asset and a lease liability. The lease liability is measured at the present value of lease payments, and the measurement of the right of use asset should be adjusted based on the amount of the lease liability [14]. For subsequent measurement, the right of use asset should be depreciated on a straight-line basis consistent with similar property, plant and equipment, and the lease liability should be amortized with the rent paid [15]. However, the main accounting process will remain the same for lessors [16], and they still make a distinction between operating leases and finance leases. Besides, the new standard enhances the disclosure requirements of lessors, which can contribute to more complete information. For transition, IFRS16 is effective from 1 January 2019. The previous accounting treatments of finance leases continue, and lessees have the option for full or limited retrospective approach to dispose operating leases [1]. Under IFRS16, all operating leases except certain leases need to be accounted as finance leases, which will have significant impact on financial statements and relevant financial ratios. In the statements of financial position, due to capitalized right of use assets and lease liabilities, total assets and total liabilities will increase. Total assets and total liabilities increase by the same amount, but the increased proportion of total liabilities is more than total assets, so the debt to asset ratio will rise. The debt to asset ratio can evaluate the risk of the company by measuring the amount of total assets that are financed by creditors. Although the debt to asset ratio will rise, the adjusted result can reveal the hidden risk of the company. In the statements of comprehensive income, the depreciation expense of right of use assets and the interest on lease liabilities should be separate. Asset turnover ratio (revenue over total assets) can measure the ability of a company using total assets to generate revenues, and high asset turnover ratio can imply that the company utilizes its assets efficiently. The revenue will remain unchanged, but the asset turnover ratio will decrease owing to the increase in total assets. Because the lease liabilities will gradually reduce with amortization, the amount of interest expense in the earlier accounting period is higher than that in the later accounting period. Under IFRS16, earnings before Interest, taxes, depreciation and amortization (EBITDA) will increase, because the original lease expenses are replaced as depreciation expense and interest expense, and the types of expenses are not included in EBITDA. In the cash flow statement, as the result of the change of operating leases, cash from operating activities will decrease, and cash from finance activities will increase correspondingly, so the total cash flows will not change, but the composition of cash flows will change. Moreover, Adoption of the new standard IFRS16 will lead to relevant tax considerations [17]. For example, the potential impact on deferred tax in statements of financial position should be considered. Admittedly, the impact on tax treatment of leasing transactions will depend on related tax policies in different countries. Consequently, the new standard has some advantages compared with IAS17. Firstly, almost all operating leases will be treated as finance leases, and the companies need to recognize assets and liabilities arising from both operating and finance leases, so the companies are required to provide more transparent statements of financial position. Secondly, the new standard can improve the comparability. Under IAS17, the companies would tend to operating leases with off-balance sheet disclosure, but the financial situation of the company might not be reflected faithfully. After the adjustment, investors can compare relevant financial performances of companies in the similar size more directly.

\section{The Impact on Airlines}

The implement of new standard will significantly affect some industries such as airline business, because the airlines need to rent aircrafts, airport facilities and some properties for their offices. PwC has conducted a research for the effect of IFRS16 on more than 3,000 listed companies around the world, the median increase in debt of airlines is approximate $47 \%$, and the increase in EBITDA is about 33\% [18]. China Southern Airlines, Air China and China Eastern Airlines are three main airlines in China, and they are listed on Hong Kong Exchanges and Clearing Market (HKEX), so they need to report financial statements in accordance with IFRS16, and this paper will focus on Air China. The airlines have three ways to introduce aircrafts, including self-buying, finance lease and operating lease.

Table 1. China Southern Airlines fleet structure.

\begin{tabular}{lllll}
\hline Year & Self-owned & $\begin{array}{l}\text { Under } \\
\text { finance lease }\end{array}$ & $\begin{array}{l}\text { Under } \\
\text { operating lease }\end{array}$ & $\begin{array}{l}\text { Total } \\
\text { number }\end{array}$ \\
\hline 2015 & $36.43 \%$ & $29.69 \%$ & $33.84 \%$ & 667 \\
2016 & $36.18 \%$ & $29.06 \%$ & $34.76 \%$ & 702 \\
2017 & $36.74 \%$ & $28.25 \%$ & $35.01 \%$ & 754 \\
\hline
\end{tabular}

Source: China Southern Airlines 2015-2017 annual reports

Table 2. Air China fleet structure.

\begin{tabular}{lllll}
\hline Year & Self-owned & $\begin{array}{l}\text { Under } \\
\text { finance lease }\end{array}$ & $\begin{array}{l}\text { Under } \\
\text { operating lease }\end{array}$ & $\begin{array}{l}\text { Total } \\
\text { number }\end{array}$ \\
\hline 2015 & $40.68 \%$ & $30.51 \%$ & $28.81 \%$ & 590 \\
2016 & $41.41 \%$ & $27.61 \%$ & $30.98 \%$ & 623 \\
2017 & $42.14 \%$ & $26.87 \%$ & $30.99 \%$ & 655 \\
\hline
\end{tabular}

Source: Air China 2015-2017 annual reports 
Table 3. China Eastern Airlines fleet structure.

\begin{tabular}{lccll}
\hline Year & Self-owned & $\begin{array}{l}\text { Under } \\
\text { finance lease }\end{array}$ & $\begin{array}{l}\text { Under } \\
\text { operating lease }\end{array}$ & $\begin{array}{l}\text { Total } \\
\text { number }\end{array}$ \\
\hline 2015 & & $74.02 \%$ & $25.98 \%$ & 535 \\
2016 & $36.66 \%$ & $38.90 \%$ & $24.44 \%$ & 581 \\
2017 & $39.39 \%$ & $37.48 \%$ & $23.13 \%$ & 627 \\
\hline
\end{tabular}

Source: China Eastern Airlines 2015-2017 annual reports

From the proportion of operating leases of fleet in three years, China Southern Airlines tends to choose operating leases to expand its scale of fleet compared with finance leases, because the previous standard did not require to disclose operating leases on statements of financial position, but the new standard would have greater effect on China Southern Airlines. From the data of China Eastern Airlines, the proportion of operating leases of fleet in 2017 has decreased compared with the proportion in 2016 and 2015, and it might illustrates that China Eastern Airlines has taken some measures to reduce the proportion of operating leases for mitigating the influence of the new standard. For Air China, the proportion has no obvious change from 2016 to 2017. However, the total amount of operating lease commitments related to office premises, aircraft and flight equipment of Air China in 2017 has decreased, and the proportion of operating lease commitments to total assets has declined to $21.81 \%$.

Table 4. Air China (RMB million).

\begin{tabular}{llll}
\hline Year & Total assets & $\begin{array}{l}\text { Operating lease } \\
\text { commitments }\end{array}$ & $\begin{array}{l}\text { Operating lease } \\
\text { commitments/Total assets }\end{array}$ \\
\hline 2015 & 213,631 & 40,139 & $18.79 \%$ \\
2016 & 224,051 & 52,171 & $23.29 \%$ \\
2017 & 235,645 & 51,391 & $21.81 \%$ \\
\hline
\end{tabular}

Source: Air China 2015-2017\%annual reports

As a lessee, the impact on financial statements has been discussed. After discounting, the right of use asset and the lease liability will be measured initially based on the present value of these operating lease commitments.

Table 5. Air China in 2017.

\begin{tabular}{ll}
\hline Time & Operating lease commitments (RMB million) \\
\hline Within one year & 6,991 \\
After one year but & 22,779 \\
within five years & 21,622 \\
Over five years & 51,391 \\
Total & \\
\hline
\end{tabular}

Source: Air China 2017 annual report

According to Air China 2017 annual report, the fixed interest rate of bank and other borrowing is in the range of $2.39 \%$ to $5.40 \%$ [10]. To simply the calculation, the discount rate is assumed to $5 \%$, and the longest term of the operating lease contracts is 10 years.

Table 6. Air China estimated lease liability.

\begin{tabular}{ll}
\hline Time & lease liability (RMB, million) \\
\hline Within one year & 6,658 \\
After one year but within five years & 19,203 \\
\hline
\end{tabular}

\begin{tabular}{ll}
\hline Time & lease liability (RMB, million) \\
\hline Over five years & 14,635 \\
Total & 40,496 \\
\hline
\end{tabular}

(Calculations in Appendix)

After debiting the right of use asset and crediting the lease liability, total assets and total liabilities will increase, and involved financial ratios also will change.

Table 7. Air China in 2017.

\begin{tabular}{lll}
\hline Project & Under IAS 17 & Under IFRS 16 \\
\hline Total assets (RMB million) & 235,645 & 276,141 \\
Total liabilities (RMB million) & 140,786 & 181,282 \\
Revenues (RMB million) & 124,026 & 124,026 \\
Debt to asset ratio & $59.7 \%$ & $65.6 \%$ \\
Asset turnover & 0.53 & 0.45 \\
\hline
\end{tabular}

(The calculation of the right of use asset has been simplified.)

Table 8. The debt to asset ratio.

\begin{tabular}{llll}
\hline Year & China Southern Airlines & Air China & China Eastern Airlines \\
\hline 2015 & $73.3 \%$ & $68.9 \%$ & $79.8 \%$ \\
2016 & $72.6 \%$ & $65.9 \%$ & $75.3 \%$ \\
2017 & $71.4 \%$ & $59.7 \%$ & $74.4 \%$ \\
\hline
\end{tabular}

Source: China Southern Airlines, Air China and China Eastern Airlines 2015-2017 annual reports

From the debt to asset ratios of the three airlines, the ratios have decreased in 2017, but the debt to asset ratios of China Southern Airlines and China Eastern Airlines have exceeded $70 \%$, which indicates that the airline business has high liabilities. Because of recognizing operating leases, the debt to asset ratio will increase, and the lender such as the bank would reevaluate whether to provide a loan for the company, but the adjusted data can help creditors and investors to assess the company. Moreover, most of aircraft leases are denominated in U.S. dollar for Chinese airlines [18], so the lease liability will be adjusted as a result of fluctuation in exchange rate, and it might have a great influence on the current profit and loss. Faced with these challenges, the group might need to communicate with shareholders to explain the changes in financial statements and negotiate with lessors about the lease contracts. For future lease contracts, the company should reassess whether buying an asset would be more beneficial than leasing it, or choosing the short-term leases rather than long-term leases.

\section{Conclusion}

Under the new standard, lessees are required to use a single accounting model for almost all leases except short-term leases and low-value leases. Meanwhile, lessor accounting is substantially unchanged. As lessees, the financial statements and relevant financial ratios of airlines will be affected. Trough adjusting Air China financial statements, relevant changes have been revealed. Total liabilities, total assets, the debt to asset ratio and EBITDA will increase after recognizing right of use assets and lease liabilities, and the asset turnover ratio will decrease. Due to increased debt to asset ratio, 
external financing will be more difficult. Therefore, airlines should not underestimate IFRS16 effect, and they might need to adjust the business plan about leasing to adapt to the new accounting standard. More importantly, Chinese airlines should consider the effect of the fluctuation of U.S. dollar. Finally, the new standard can intensify the comparability and transparency of financial statements.

\section{Appendix}

Table 9. Present Values Calculations.

\begin{tabular}{llll}
\hline Rate & Nper (AVG) & FV & PV \\
\hline $5 \%$ & 1 & 6,991 & 6,658 \\
$5 \%$ & 3.5 & 22,779 & 19,203 \\
$5 \%$ & 8 & 21,622 & 14,635 \\
\hline
\end{tabular}

(PV function in Excel)

\section{References}

[1] IASB. (2016). IFRS 16 Leases. [Online]. Available from: https://www.ifrs.org/issued-standards/list-of-standards/ifrs-16leases/ [Accessed: 14/12/2018].

[2] Giner, B. \& Pardo, F. (2018). The Value Relevance of Operating Lease Liabilities: Economic Effects of IFRS 16. Australian Accounting Review. Vol. 28 Issue. 9 p495-511.

[3] Kabir, H. \& Rahman, A. (2018). How Does the IASB Use the Conceptual Framework in Developing IFRSs? An Examination of the Development of IFRS 16 Leases. Journal of Financial Reporting. Vol. 3 Issue. 1 p93-116.

[4] Zamora-Ramirez, C. \& Morales-Diaz, J. (2018). Effects of IFRS 16 on Key Financial Ratios of Spanish Companies. Estudios de Economia Aplicada. Vol. 36 Issue. 2 p385-405.

[5] Morales-Diaz, J. \& Zamora-Ramirez, C. (2018). The Impact of IFRS 16 on Key Financial Ratios: A New Methodological Approach. Accounting in Europe. Vol. 15 Issue. 1 p105-133.

[6] Yu, H. Y. (2017). Analysis on the Impact of the application to IFRS 16 by China Southern Airlines [D]. Beijing Jiao Tong University.
[7] Xu, F. \& Liu, S. C. (2018). The Impact of IFRS16 Leasing Standard on Airlines: Taking Eastern Airlines as an Example. MODERN ACCOUNTING. Issue 9 p18-24.

[8] PwC. (2016). IFRS 16-The new leases standard. [Online]. Available from: https://www.pwc.com/gx/en/services/audit-assurance/assets/ifr s-16-new-leases.pdf [Accessed: 19/12/2018].

[9] China Southern Airlines 2015-2017 Annual Reports.

[10] Air China 2015-2017 Annual Reports.

[11] China Eastern Airlines 2015-2017 Annual Reports.

[12] IASB. (2003). IAS 17 Leases. [Online]. Available from: https://www.ifrs.org/issued-standards/list-of-standards/ias-17-1 eases/ [Accessed: 14/12/2018].

[13] Deloitte. (2016). Leases A guide to IFRS 16. [Online]. Available from: https://www2.deloitte.com/content/dam/Deloitte/sg/Document s/audit/sea-audit-IFRS-16-guide.pdf [Accessed: 15/12/2018]

[14] Stebbens, P. et al. (2016). IFRS 16 Leases Overview. [Online]. Available from: https://assets.kpmg.com/content/dam/kpmg/pdf/2016/03/ifrs1 6-leases-webinar-presentation-slides-march-2016.pdf [Accessed: 18/12/2018].

[15] KPMG. (2016). IFRS 16: Leases- A Step towards a more Transparent Balance sheet. [Online]. Available from: https://assets.kpmg.com/content/dam/kpmg/ng/pdf/audit/ifrs-1 6-leases-a-step-towards-a-more-transparent-balance-sheet.pdf [Accessed: 21/12/2018].

[16] EY. (2018). IFRS 16 Lease overview and EY's enabling toolkit. [Online]. Available from: https://www.ey.com/Publication/vwLUAssets/EY___IFRS 16 _Lease_Workshop/\$FILE/EY_IFRS\%2016_Lease_Workshop. pdf [Accessed: 28/12/2018].

[17] PwC. (2017). At a glance Tax accounting considerations of IFRS 16. [Online]. Available from: https://www.pwc.nl/nl/assets/documents/tax-accounting-consi derations-of-ifrs 16.pdf [Accessed: 20/12/2018].

[18] PwC. (2016). In the Spotlight Impact of IFRS 16 to Airlines. [Online]. Available from: https://www.pwccn.com/en/ifrs/ifrs 16-aerospace-may2016.pdf [Accessed: 27/12/2018]. 